\title{
History of Newspaper in Afghanistan
}

\section{Sabghatullah $\mathbf{G}^{*}$}

School of Journalism and Communication, Hebei University, Baoding, China

\begin{abstract}
Afghanistan has been known one of the most unstable countries in the world for more than three decades. It has suffered from both foreign and civil wars and still it has been experiencing a tragic conflict across the country.

The core purpose of this study is to explore the history of newspapers in Afghanistan. In the past, there were many kings who ruled Afghanistan, and the new King was not interested to accept old publications of newspapers. Therefore, Afghanistan has witnessed many authors and companies of newspaper publications. However, due to limited time, this study covers a brief history of newspaper. Shamsul Nehar (known as a sunny day) was the first publication and newspapers in Afghanistan under the responsibility of Sayed Jamalodin Afghan.
\end{abstract}

\section{Keywords: Newspaper; Afghanistan; Shamsul Nehar}

\section{Introduction}

Nowadays, newspaper plays a significant role in our life. It is the first thing that every member around the world read in the morning. It has justified as a main source of keeping us up to date about all news that happen across the country or world. Organizations such as trade unions, religious groups and corporations have their own newspapers, but the term is more commonly used to refer to daily or weekly publications that bring news of general interests to large portions of the public in a specific geographic area [1].

Newspaper provides information about security, politicians, social issues, business and sports. To make it more clear, newspaper keeps us update and develops our general knowledge on the daily basis [2]. Everyone industry publishes newspaper for their own benefits. Manufacturing and service organizations advertise their goods and services in the newspapers, it promotes their sales. From the public perspective, newspaper builds nations, and newspaper normally suggests constructive paths for the development.

This research paper discusses the history of newspaper in Afghanistan. This country has over hundred years long history in newspaper, but the establishment of newspaper is still unstable and unclear. With the arrival of first printing press (Lithography printing) to Afghanistan from India in 1873, newspaper started across the country. For the first time, in 1873, Sayed Jamaludin Afghan requested for the newspaper. Shir Ali Khan (King of Afghanistan) was the first leader to support newspaper publications. With this the first issue of Shamsul Nehar (known as a sunny day) was printed. It was a periodical and it seems that between 40-48issues were published [3]. On January $11 / 1906$, the second periodical of Seraj-ul-Akhbar (known as a "lamp of news") was printed. Seraj-ul-Akhbar was not a positive newspaper for the friendship between Afghanistan and the United Kingdom, and was against the idea of colonialism. However, after this issue, the newspapers were stopped. Newspaper restarted in 1911 by Mohmoud Tarzi, known as a "Father of Afghan Journalism". Mohmoud Tarzi was the editor and owner of the Seraj-ul-Akhbar. In 1919, under Amanullah Khan (King of Afghanistan) power, Seraj-ul-Akhbar (known as a "lamp of news") was replaced by Aman-e-Afghan serving as key organ of the government. At the same time, some smaller private journals appeared under different ministries. Alongside these developments, radio broadcasting began for the first time in 1925, which was added to mass media [4].

\section{Literature Review}

This paper is mainly based on the secondary data, and the data was collected from Pashto and Persian language resources. The researcher could not find a single source by English language.

However, press in Afghanistan will start in a real sense after the formation of a new Afghanistan. Previously, Afghanistan people were not united, and they had a lot of problems. Along with this, neighbours used to threaten Afghanistan borders [5]. In this regard, Shamsul Nehar (sunny day) argues that for the first time Afghan people, and in particular the citizens of Kabul were able to become more or less familiar with the concept of the press and its importance in life [6]. In addition, in 1873 Amir Sher Ali Khan was a King of Afghanistan regime, at that time Shamsul Nehar (sunny day) newspaper was launched for the first time, and Mirza Abdul Ali Khan was head of the first lithographical printing press [7].

\section{First Newspaper}

Sayed Jamaludin Afghan and Mahmoud Tarzi were the first people who launched journalism in Afghanistan. They both have accomplished a large amount of work in the field of journalism. Mahmoud Tarzi, one of his earliest works was known as a journey (Sayahat-Namah-e Manzum), it was published in Lahore, British, and India (now Pakistan). However, Tarzi main foundation of journalism existed in Afghanistan.

According to some historians, first newspaper of Afghanistan was before Shamsul Nehar, and it was called Kabul Newspaper in the duration of King Amir Mohammad Azam Khan. However, most authors and historians believe that the first author of newspaper publication was Shamsul Nehar, and around 40-48 issues were published [3].

*Corresponding author: Sabghatullah G, School of Journalism and Communication, Hebei University, Baoding, China, Tel: + 86312507 9698; E-mail: sabghatullah_123@yahoo.com.au

Received March 08, 2018; Accepted April 19, 2018; Published April 23, 2018

Citation: Sabghatullah G (2018) History of Newspaper in Afghanistan. J Mass Communicat Journalism 8: 370. doi: 10.4172/2165-7912.1000370

Copyright: ( 2018 Sabghatullah G. This is an open-access article distributed under the terms of the Creative Commons Attribution License, which permits unrestricted use, distribution, and reproduction in any medium, provided the original author and source are credited. 
The second newspaper of Afghanistan was Seraj-ul-Akhbar (was known as a Lamp of the news), and this newspaper publication started in 1911. Newspaper was published in Persian (Afghani Dari) language [8]. Has demonstrated that Seraj-ul-Akhbar newspaper publication was very consistent and reliable, and this newspaper was published in every 15 days. It was the first newspaper, which brought modernist ideas and new political and cultural terms into Afghan society. Serajul-Akhbar was more interested in publishing national ideas and it was against British opinions, and this was the main reason that this newspaper were stopped after eight years [9].

Afghanistan gained independence from the United Kingdom on August 19, 1919. Newspaper publication was restarted again. Founder Mahmoud Tarzi was outspoken and opposed, among other things, the official position of friendship between the United Kingdom and Afghanistan. Seraj-ul-Akhbar (Lamp) was replaced by Aman-i-Afghan, after King Shir Ali Khan was died. From that initial period of attempted enlightenment, until the 1950s through 1970s, when professional journalists facilitated a brief period of growth, Afghani journalism remained limited and mostly a vehicle for resonance with ruling thought [3]. In the regime of King Ghazi Amanullah Khan in 1927s, the publication of newspaper was growing fast. Many newspapers publication were launched, such as Arshad-ul,Naswan (guidance for women), Seraj-ul-Atfal (Lamp of children), Satara E- Afghan (Star of Afghan), Pashtun ghag (voice of Pashtun), Anis (Companion or friendship, Urdo (Army), Nasim Sahar (breeze), Etehad- E-Mashragi (unison of east), Etefaq E Islam (unison of Islam), Baidar (Bravery), Tolo E Afghan (Blooming of Afghan), Islah (Renovation), Soorwat (riches), Haqiqat (true), Ghazi (participant of a holy war), Nawrooz (first day of year), and Majmoa E Sahia (collection of healthy) [10].

The above newspaper publications were part of government, but three of these were free newspapers, such as Nasim Sahar (breeze), Nawrooz (first day of New Year) and Anis (companion or friendship). Has pointed out that after seven years in 1934s, Anis newspaper was transformed to governmental press. During the King Amanullah Khan period, other initiatives inaugurated the press Law of Afghanistan, the press law is included in Afghan constitution. According to the press law it explained in 11 paragraph of the Afghan constitution, establishing of publication was given only to the government [11].

Afghanistan is one of the countries, which is known for war and revolutions. It has suffered from both foreign and civil war for more than three decades. Afghanistan had many kings, and every king had a new policy, strategy and ideology about press. New king did not allow old newspapers, and launched new newspaper with different names. Therefore, it is difficult for a student to collect and mention all newspaper in one article. Restricted press life and low readership levels extended backward well beyond the Taliban. In fact, only one period may have permitted the operation of truly independent journalism, the supposed decade of democracy (1963-73), under the rule of King Zahir Shah, and Pakistan's last monarch who reigned from 1933 to 1973. However, with his overthrow, media restriction increased under president Mohammad Daud (1973-78), the Communist People Democratic Party of Afghanistan (1978-92), the provincial Mujahedin (fighters in a holy war) (1992-96), and the Taliban (1996-2002) [12]. In 2016, the two most influential governmental dailies were Anis (Companion or Friendship), which was founded in 1927 with circulation estimated at 25,000 and published in Dari, also some publications were written in Pashto and Uzbek. The second is Hewad (homeland), which was founded in 1959 with a circulation estimated 12,000 all articles were written in Pashto. Both are based in Kabul and controlled by the
Ministry of Information and Culture [13]. In 2008s, other principle governmental publications, estimated not more than 120 , headquarter was located in Kabul and some branches were in the some province like Baghlan, Faizabad, Frah, Gariz, Hearat, Jalabad, Mazar-i- Sharif, Shiberghan, Kandahar and etc. These provincial papers mostly relied on the Kabul dailies for news and average around 1,500 in circulation, and except governmental publications. Afghanistan had more private publications than public in 2008s, and publications number increased to 611 , but now some of these have stopped [14].

\section{Conclusion}

One author, Amin Tarzi in an article in 2006 to RFE/RL described Afghanistan's independent media history as this; Afghanistan's first experiment with an independent media sector began in the late 1940s and was restricted solely to newspapers. Prime Minister Shah Mahmud allowed relatively open elections and the establishment of what has come to be known as the "Liberal Parliament."

The new legislature soon passed a press law that led to the launching of several newspapers -- most of which were in opposition to the monarchy, the prime minister, or both. Conservative religious figures and their supporters in the government were the most frequent targets of attack. The experiment ended abruptly in 1953 when president Mohammad Daud Khan became Prime Minister and ordered the closure of independent newspapers.

The country's second major experiment with independent media began with the promulgation of the 1964s Afghan Constitution by King Mohammad Zaher. That document ushered, in what is commonly referred to as Afghanistan's "decade of democracy". The constitution decreed that "every Afghan has the right to express his thoughts in speech, in writing, in pictures, and by other means, in accordance with the provisions of the law". The 1964s constitution further states that every Afghan has the right to print and publish ideas in accordance with the law, without prior screening by state authorities.

\section{References}

1. Khogyani MA (1939) Life of Sayeed Jamaludin. KABUL: KABUL Press.

2. Joia MS (1932) A commentary on our press89. Kabul: Kabul megazine.

3. Alan Bass (2001) Journalism in Afghanistan: Getting better but still a long way to go. J Source.

4. Chandrasekaran R (2007) Father of journalism. JSTOR 31: 89-91.

5. Hashami SS (1972) Contemporary History. Kabul: Kabul University.

6. Habibi A (1958) fourty year's journalism in Afghanistan. Salnama ey Kabul, 89

7. Shelley (2007) A Brief History of Journalism.CRUTZ.

8. Nordland R (2014) In Brutal Year, 7th Journalist Is Killed in Afghanistan. N Y Times.

9. Griswold E (2012) Afghanistan: The E-bookseller of Kabul. Pulitzer Center.

10. Hasham AM (2003) system of press in Afghanistan. Kabul: Aksos.

11. Kabeer N (2006) decade Constitution of Afghanistan. Peshawar: Peshawar press.

12. Ahmadi J (2005) Development of Traditional Media. Kabul: Khmoosh Press

13. Ahmadi B, Lakhani S (2017) The Afghan Refugee Crisis in 2016. Peace Brief.

14. Ibrahimi AA, Walizada A (2017) Suicide bombers kill dozens at Shi'ite center in Afghan capital. Reuters. 